Acta vet. scand. $1968,9,285-301$.

From the Department of Medicine, Veterinary College of Norway, Oslo.

\title{
THROMBOCYTOPENIC PURPURA IN BABY PIGS GLINICAL STUDIES
}

\author{
By \\ Halldis Lie
}

Thrombocytopenic purpura in pigs was first reported from Norway by Stormorken et al. (1963). They concluded that the disease is caused by incompatibility between maternal isoantibodies and platelets of the newborn.

The disease has been observed also in the United Kingdom (Saunders et al. 1966), in Sweden (Henricson 1964, Thörne \& Håkanson 1967) and presumably also in Finland (Henriksson 1965 ).

In this country additional spontaneous cases have occurred, often resulting in severe losses of piglets within litters.

The present report deals with studies on spontaneous as well as experimental cases of thrombocytopenic purpura.

\section{MATERIAL AND METHODS}

Six sows, S1-S6, of Norwegian Landrace breed, which had produced litters affected with purpura, were purchased for breeding. Five of these farrowed 1 or more litters, altogether 11 litters.

Four of these sows are the same as those mentioned by Lie (1966): $\mathrm{S} 1=\mathrm{G}, \mathrm{S} 2=\mathrm{E}, \mathrm{S} 3=832$ and $\mathrm{S} 4=842$. In this article the sows are numbered chronologically.

Three boars, Y, L1 and L2, were used for breeding. Boar Y, of the Yorkshire breed, was the father of the affected litter of S2. The platelets of this boar were agglutinated by the sera of S1 and S2 (anti-A, Lie 1966), while those of boar L1, of Norwe- 
gian Landrace breed, were not. Boar L2 was son of S3 and L1, piglet no. 981. The platelets of this boar were not agglutinated by the serum of S3.

The piglets were subjected to platelet counts from birth to $2-5$ weeks of age. Leucocyte number and packed red cell volume (PCV) were determined for piglets from 9 of the litters.

These piglets were normally kept under the same conditions as normal piglets (Lie 1968). Those which were fed artificially received cattle milk to which was added 1 egg and 1 tablespoon of a mineral solution per liter (the solution was composed of ferrous sulphate $50 \mathrm{~g}$, copper sulphate $4 \mathrm{~g}$, manganese sulphate $3.5 \mathrm{~g}$, potassium iodide $0.25 \mathrm{~g}$ and distilled water ad $1000 \mathrm{~g}$ ).

The investigations on the spontaneous cases are, however, deficient, as these cases were observed and reported by practitioners. Thus these piglets arrived in the clinic when the purpura had lasted for 1 day or more.

Platelet and leucocyte counts and PCV were determined as described for the normal material (Lie 1968). The results of platelet and leucocyte counts are given as $1000 / \mathrm{mm}^{3}$, the $\mathrm{PCV}$ is given as volume per cent.

When platelets were to be prepared for testing or absorption of sera, at least $15 \mathrm{ml}$ of blood was taken from the aperture. As anticoagulant, EDTA was used (Lie 1968). To the antisera was added 1/10 vol. of EDTA before use (Lundevall 1958).

The piglets were 2--3 months old when their platelets were tested with the serum from their mother. From a piglet with thrombocytopenia it is difficult to get enough platelets for an agglutination test. At the age of 2-3 months, however, the surviving pigs had usually recovered completely even if they had suffered from severe thrombocytopenia.

Absorption of platelet antibodies: The method of Lundevall was used.

Platelet agglutination test: The shaking method was used. This method, which was introduced by Dausset (1954), is detailed by Lundevall. One drop of serum was mixed with 1 drop of washed platelets on a tile and incubated at room temperature in a shaking machine for $1 / 2 \mathrm{hr}$. After an additional $1 / 2 \mathrm{hr}$., the tile was shaken by hand and readings made in a dark field microscope at $100 \times$ magnification. Repeated readings were made $1 / 2$ hr. later. 

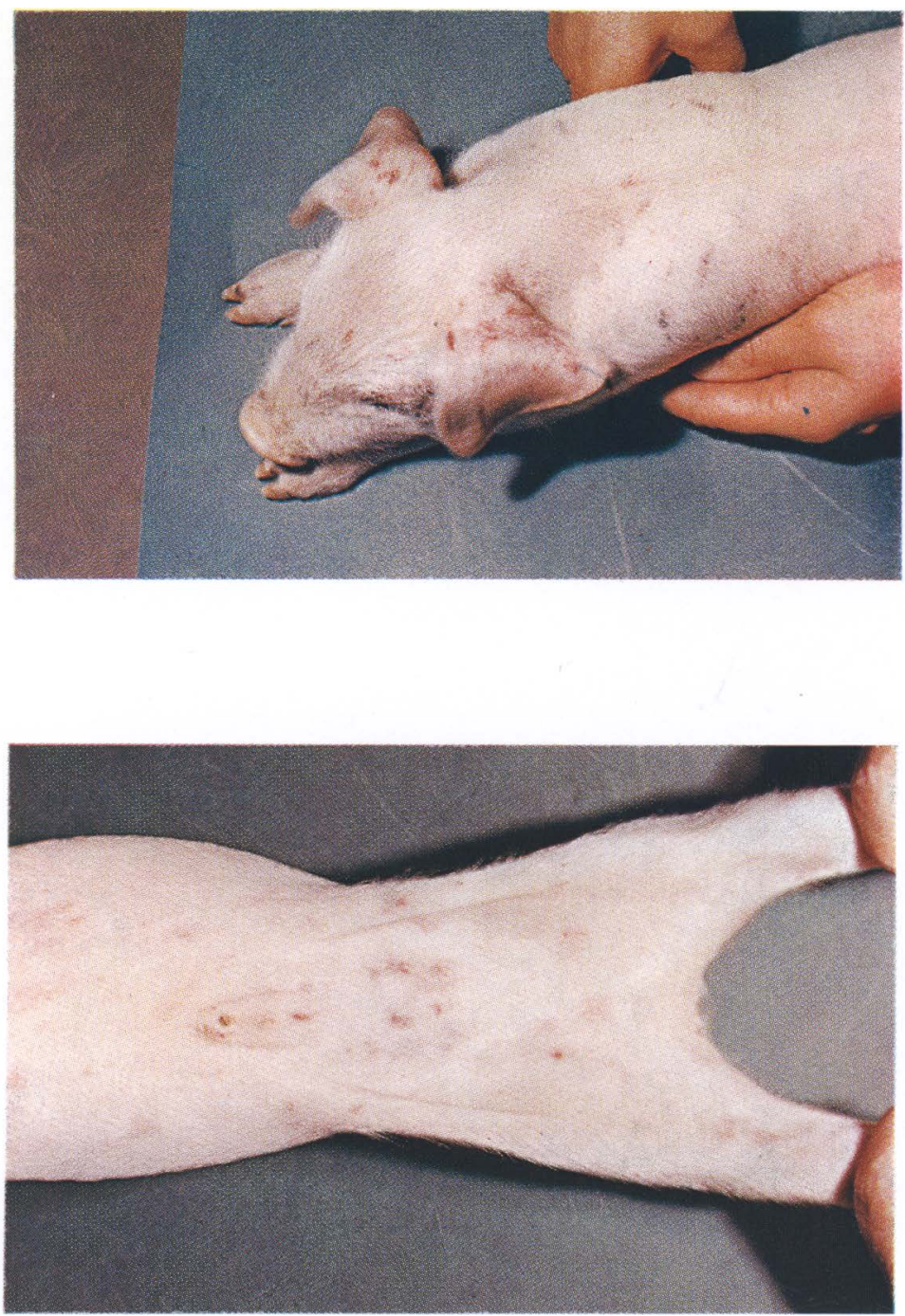

Fig u r e s 1 and 2.

Thrombocytopenic purpura in a piglet 8 days old. 



\section{RESULTS}

S1. This sow farrowed a litter of 9 in June 1962. All the piglets were apparently healthy until the 6th day of life when the first symptoms of purpura were observed. Two of the baby pigs died on the 8th day. At this time we had the opportunity to examine the remaining piglets. These were big and well fed, but drowsy and anemic. All presented purpura, mostly on the ears, the abdomen and on the inner, proximal parts of the limbs. The bleedings were different in size, from pinpoint up to a diameter of $2-3 \mathrm{~cm}$ (Figs. 1 and 2).

Platelet counts were $10-40$. The most severely affected died the following night. Within the next 2 days 2 more died. The remaining recovered rapidly. One week later the platelet counts were $500-600$ (Fig. 3).

The platelets of the surviving piglets were all agglutinated by the serum from the mother.

The sow, which appeared to be quite healthy, had farrowed altogether 4 litters, all after matings to the same boar. According to information, the 3 preceding litters had not shown any purpura symptoms.

The sow was mated to the same boar, but did not conceive.

S2. The first 2 litters of this sow were reported to be normal. The piglets of the 3rd litter, however, showed symptoms of purpura when 15-16 days old. On arrival at the clinic on the 16th day, 3 piglets were already dead. The remaining 7 had platelet counts of $9,82,185$, $270,358,434$ and 456, respectively. The piglet with the lowest count had severe purpura and died the following night. The others did not show any symptoms of purpura.

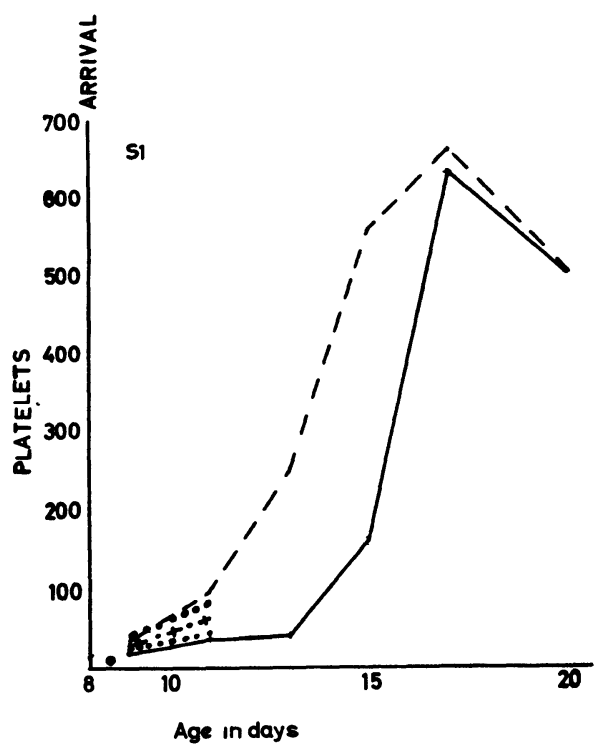

Figure 3. Platelet counts in the offspring of S1. 
The platelets of the offspring were agglutinated by the serum from the mother.

S2 was mated to boar $\mathrm{Y}$, which had sired her preceding litter. The resulting litter of 14 was divided in 2 groups, A (nos. 1-6) and $B$ (nos. 7-14), immediately after birth. Group A was not allowed to suck, but was fed artificially. Group B was allowed normal feeding.

The smallest and weakest one from each group (nos. 2 and 9) died on the 2nd day, their counts on the 1st day being 195 and 155 , respectively.

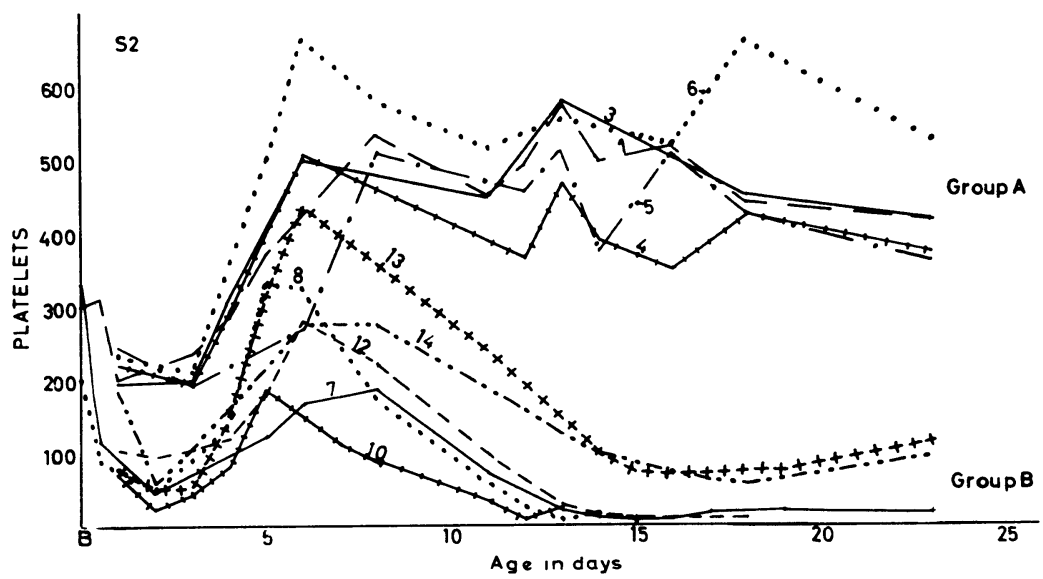

Fig u re 4. Platelet number in the 4th litter of S2. Group A without colostrum.

When the piglets were $50-55$ hrs. old, nos. 1,3 and 4 in group A were allowed to suck their mother. At the same time nos. 7, 8 and 10 in group $B$ were taken away from their mother and fed artificially. Platelet counts are shown in Fig. 4.

None of the piglets showed symptoms of purpura before the age of 11 days, except no. 10, which had a bluish-red colour on the 2nd and 3rd day after birth. When the platelet counts decreased to below 40 again, which occurred between the 11th and 13th day for 4 of the piglets (nos. 7, 8, 10 and 12), symptoms of purpura appeared. Three of these 4 pigs died at an age of $13-15$ days, whereas no. 7 survived in spite of purpura and very low platelet counts (Fig. 4). This lasted 3 weeks. Two pigs (nos. 13 and 14) in group B did not show as low platelet counts as the 4 mentioned above. Neither did they show symptoms of purpura. 
One of the piglets in group B differed markedly from the others (no. 11, not included in Fig. 4). This piglet had a severe thrombocytopenia the first 3 days of life, but were without purpura symptoms. From the 5th day on, its platelet counts were normal.

All the piglets in group A showed normal platelet counts; also those 3 which were allowed to suck their mother from 50 to 55 hrs. of age.

Serum from the mother(S2) caused agglutination when tested against platelets of all the surviving piglets.

Packed cell volume (PCV) was examined only 5 times during this period of 23 days. It seemed to be stable until purpura was developed. Then, however, it dropped quickly. As typical for the piglets with purpura, the results of no. 10 are given: The PCV was, on the 2nd and 5th day, 31 and $32 \%$, respectively. On the 11th day purpura was observed. The next day the PCV was $25 \%$ and dropped further to $13 \%$ on the 13th day. No icterus was observed. Leucocytes were not counted.

These experiments showed that the offspring of a sow with platelet antibodies in her serum had normal platelet counts before they had sucked their mother, and that the intake of colostrum the first 2 days was decisive for the development of purpura.

In the piglets which had colostrum the lowest platelet counts were observed the first 2-3 days after birth and again after the 10th day. Meanwhile the piglets had a marked increase in platelet number, which for a short time resulted in counts, that in some of the piglets were close to normal values.

During the first 2-3 days distinct symptoms of purpura were not observed in spite of platelet counts as low as 30 . In the period after the 10th day, however, purpura always appeared when the count dropped below 40 .

The course of the disease varied rather much between the different piglets, as 3 died of thrombocytopenia, 1 survived in spite of severe purpura, 2 had a more moderate thrombocytopenia without purpura and 1 had normal platelet counts from the 5 th day on.

S3. The 3rd litter of this sow showed purpura symptoms. Five of the 10 piglets died 9-11 days old. On arrival at the clinic on the 11th day the platelet counts for the remaining were $48,280,315,440$ and 532, respectively, the lowest count increasing to 255 during the 
next 9 days. Platelets from the offspring were agglutinated by the serum of the mother.

The last 2 litters were sired by the same boar, whereas the first litter resulted from a different boar. The first 2 litters were reported not to have suffered from purpura.

a. S3 was mated to boar L1. The piglets (nos. 741--748) were all allowed to suck immediately after birth. Platelet counts are shown in Fig. 5.

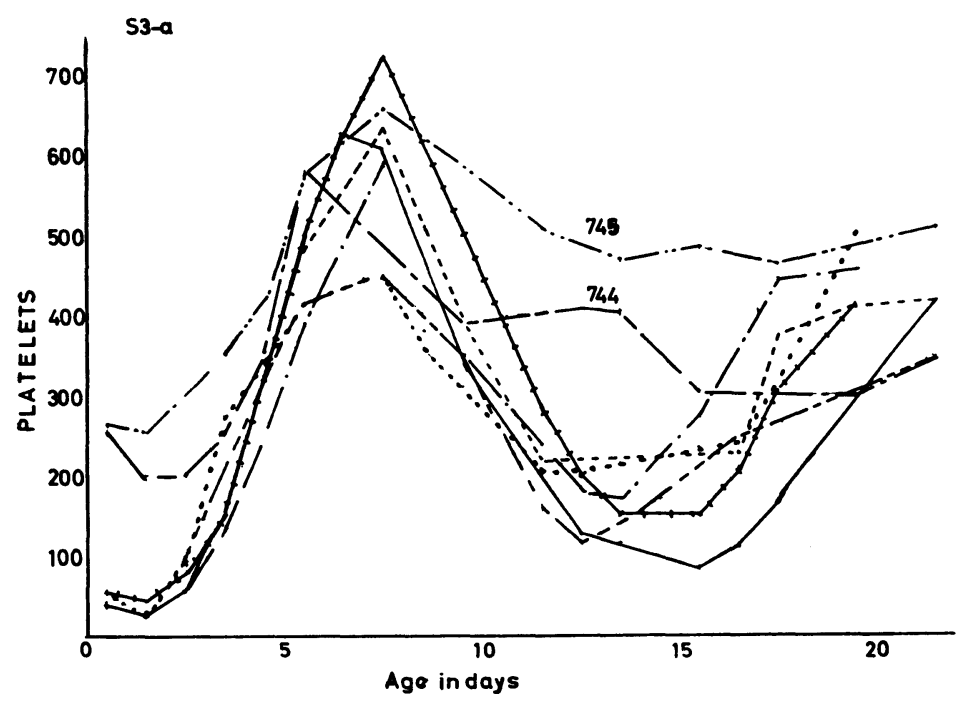

F i g u r 5. Platelet number in the offspring of S3 and boar L1.

Six of the 8 piglets had purpura as early as 8 hrs. after birth. The skin had a fresh red colour due to pinpoint bleedings all over the body. On the ears were bluish-red spots with a diameter up to $2 \mathrm{~cm}$. The piglets bled easily after puncture of the ear vein. Urine and feces were blood stained.

The purpura lasted for 2 days and did not appear later. But the piglets had thrombocytopenia again from 11 to 18 days of age, the lowest counts varying from 80 to 220 for the 6 different pigs. All the piglets survived.

The remaining 2 pigs, nos. 744 and 745, were apparently normal with normal platelet counts (Fig. 5).

Serum from S3 caused agglutination when tested against platelets from the 6 piglets whereas platelets from nos. 744 and 745 were not agglutinated. 
Absorption of the serum with platelets from the 6 pigs removed the platelet agglutinin whereas platelets from nos. 744 and 745 did not.

b. S3 was mated to boar $\mathrm{Y}$ and farrowed a litter of 6 (nos. 871-876). Platelet counts of this litter are shown in Fig. 6.
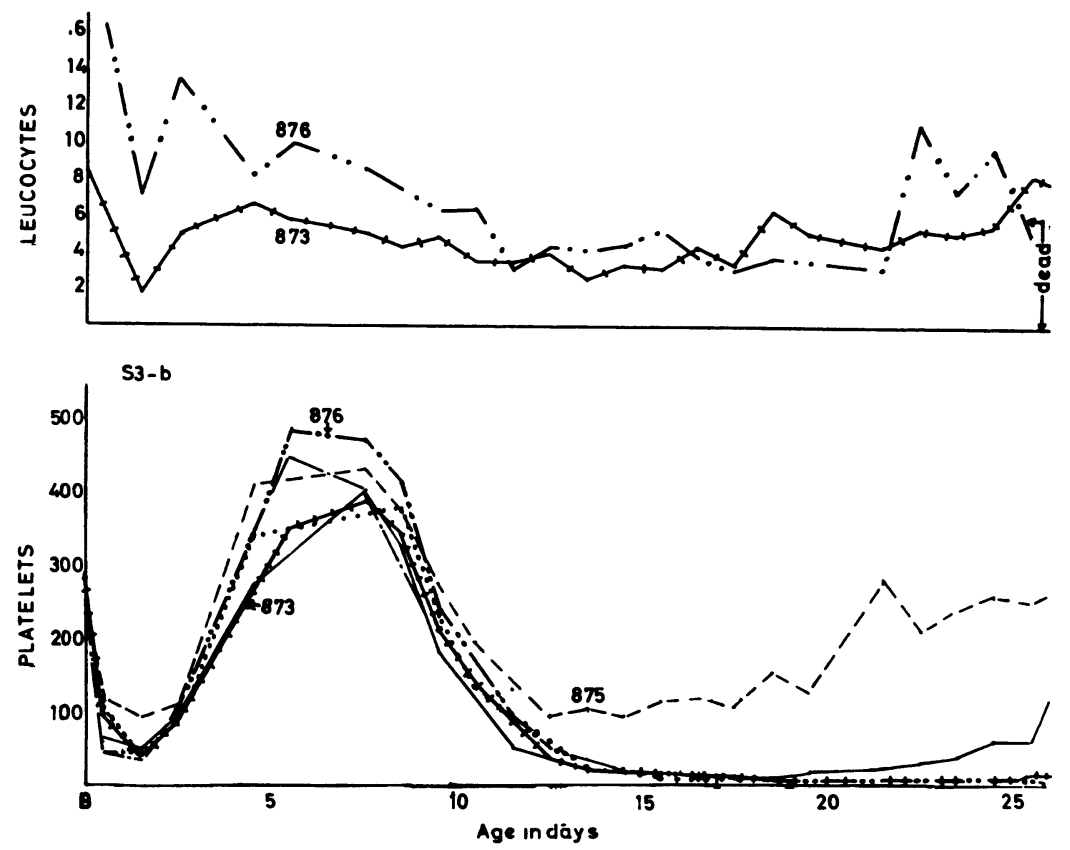

F i g u r e 6. Platelet and leucocyte number in the offspring of S3 and boar Y. As the piglets nos. 873 and 876 during the first week of life had the lowest and highest counts respectively, the results of only these 2 piglets are shown.

All the piglets, except no. 875, had slight symptoms of purpura the first 2 days of life. Leucopenia was observed. From the 4th to the 13th day no purpura could be observed. In this period the piglets were active, well fed and apparently normal. During the 13th-14th day, however, all except no. 875 got purpura. Three of them died, 16, 19 and 26 days old, respectively. Together with no. 875 the remaining 2 piglets survived in spite of severe thrombocytopenia that lasted for 2 and 3 weeks, respectively.

The PCV was normal during the first 2 weeks, was low after onset of bleedings, but increased rapidly when the symptoms of purpura disappeared. Typical curves are given in Fig. 7. 

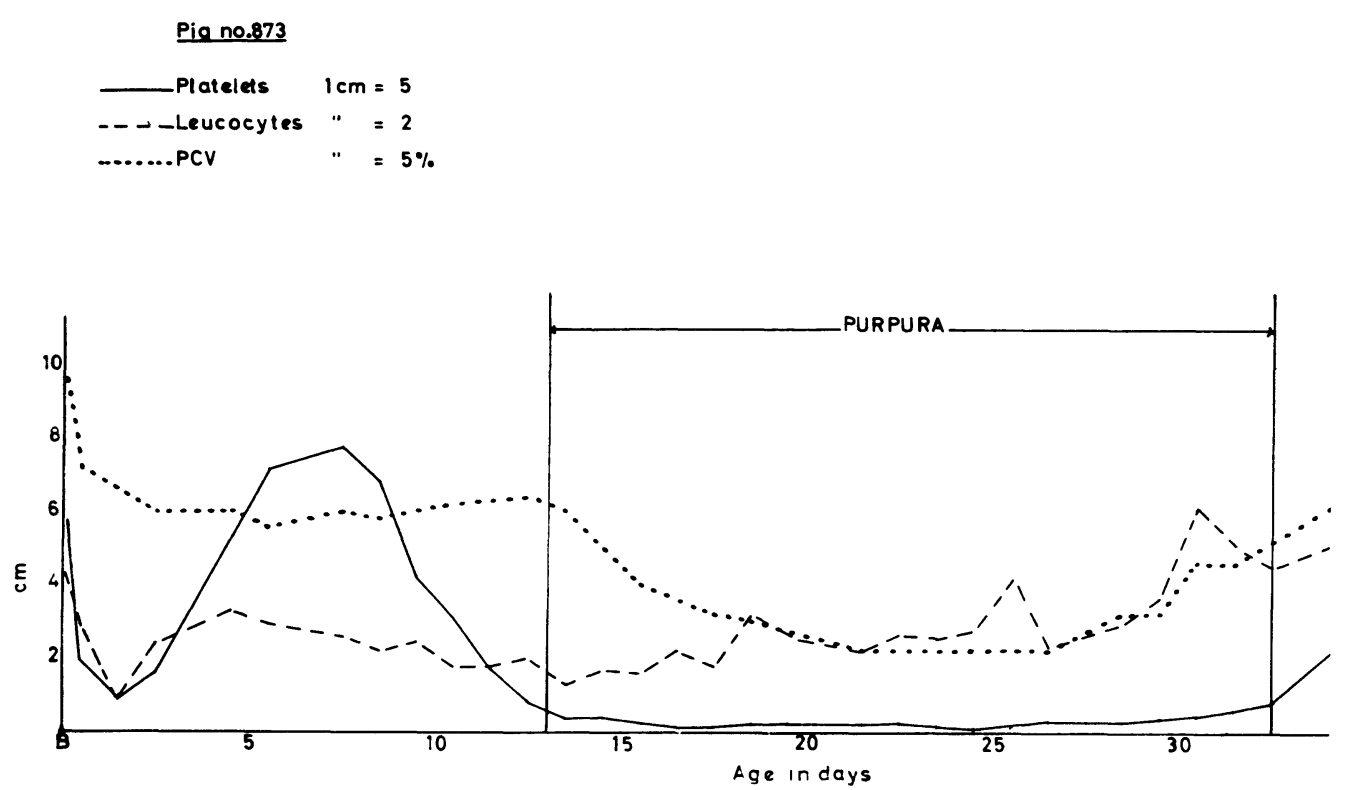

Figur e 7. Platelet and leucocyte counts and PCV \% during the first 40 days in 1 piglet from the offspring of S3 and boar Y.

Serum from the mother caused agglutination when tested against the platelets from all the surviving piglets within this litter.

c. S3 farrowed a 6th litter (nos. 981 -984) after mating to boar L1 which had sired her 4th litter. In regard to platelet counts, the course of this litter (Fig. 8) was similar to that of the 4th litter (Fig. 5), as 2 of the piglets (nos. 983 and 984) had a severe thrombocytopenia and purpura the 1st day of life. After the 2nd day, no purpura was observed. The remaining 2 piglets (nos. 981 and 982) were apparently normal and had normal platelet counts all the time. No leucopenia was observed.

Serum from the mother also showed the same difference when tested against the platelets from the respective piglets. The platelets from nos. 983 and 984 were agglutinated by the serum whereas those from nos. 981 and 892 were not.

d. S3 was mated a second time to boar $\mathrm{Y}$ and farrowed her 7 th litter. The results from this litter of 6 are similar to those of the 5 th litter (b). All the piglets had purpura, with death of 3 piglets 

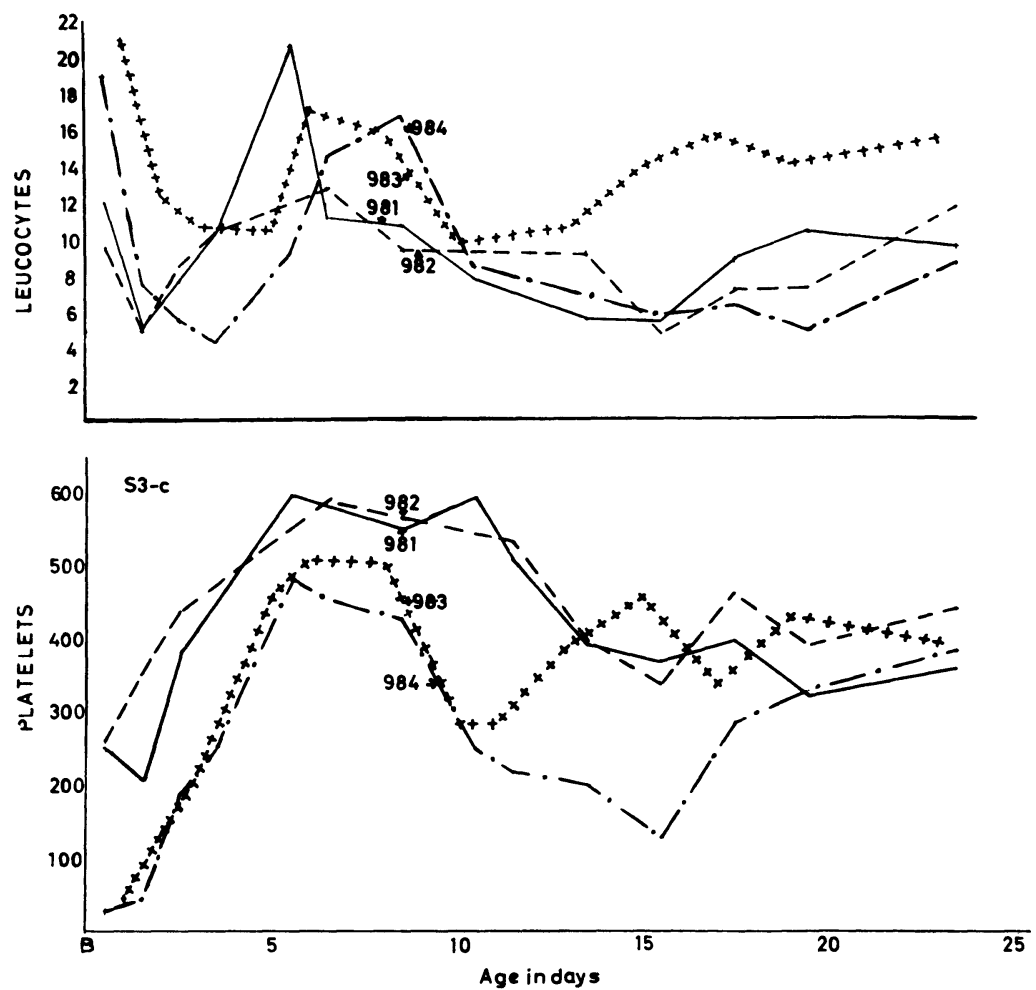

Figure 8. Platelet and leucocyte number in the offspring of S3 after a second mating to boar $\mathrm{L} 1$.

at an age of 16,17 and 20 days, respectively. Leucopenia was observed in 2 of the piglets.

Platelets of the surviving 3 piglets were all agglutinated by the mother's serum.

e. S3 was now mated to her son, boar L2 (Fig. 8, no. 981) and farrowed a litter of 4 ( +2 stillborn). One of the piglets had a hernia cerebralis and was put to death; another one was killed by the mother the first day of life. The remaining 2 had normal platelet counts all during the experiment.

The serum from the mother did not agglutinate the platelets from these 2 piglets.

The 4 litters of S3, sired by the 2 boars $Y$ and L1, were all affected with thrombocytopenia. The crossbred offspring of boar Y, however, were more severely affected than those of boar L1. 
This may be due to the fact that the offspring of boar $Y$ were all more vigorous and active just after birth and supposedly sucked more eagerly than those of boar L1. Furthermore, boar Y was presumably homozygous for the actual platelet factor while L1 supposedly was heterozygous, as some of his offspring seemed to lack the factor and thus were unaffected.

Within these 4 litters purpura was observed also during the first 2 days of life, the purpura at this time manifested mainly as pinpoint bleedings all over the body.

The last litter (e) of S3, after mating to boar L2, had no thrombocytopenia at all. This implies that a sow, in spite of previous affected litters, 'may get litters with normal platelet counts if mated to a boar lacking the actual factor.

S4. According to information, this sow had farrowed 4 litters all after matings to the same boar. The first 2 litters had apparently been normal whereas the 2 last ones had been affected with purpura. The purpura was observed from the 17 th-19th day after birth in both litters. Within the 3rd litter, 8 of 12 piglets died; within the 4th, 6 of 9 .

The sow was mated to the same boar and farrowed a litter of 9. Five of the piglets had a moderate thrombocytopenia (the lowest counts being 70,95, 120, 135 and 140, respectively) at $1-2$ days of age. Only 2 of these 5 had subnormal counts (175 and 250 respectively) again at the age of 14 days, but no purpura was observed. The remaining 4 had normal platelet counts.

Serum from the mother agglutinated platelets from all the piglets.

It has to be mentioned that the sow was not quite well during the pregnancy and parturition, as she suffered from an ulcer on the right shoulder. Half a year later she died due to an abscess in the spine.

The mild course of the disease within this last litter of S4 may be a result of the condition of the mother, as she seemed to be a bad nurser this time, the piglets thus getting only small doses of colostral antibodies.

S5. This sow was 4 years old when she gave birth to a litter affected with purpura. However, no information was given about the number of previous litters nor about the course of the disease within the last litter.

a. S5 was mated to boar $\mathrm{Y}$ and farrowed a litter of 9 (nos. 911919 ) of which no. 913 was killed by the mother the first day of life. Platelet counts are shown in Fig. 9. 


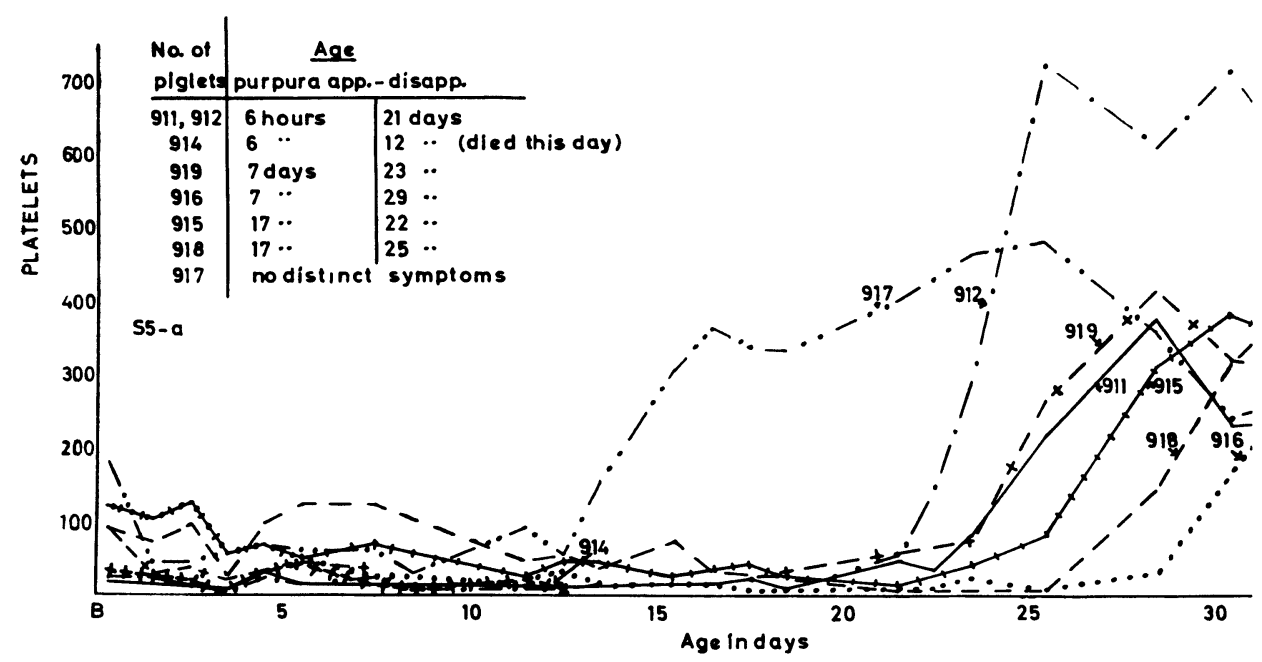

Figure 9. Platelet number in the offspring of S5 and boar Y.

When the first samples were taken $6 \mathrm{hrs}$. after birth, all the piglets had thrombocytopenia and 3 (nos. 911, 912 and 914) had already developed purpura. No. 914 died 12 days old having had purpura from birth. Nos. 911 and 912 had purpura up to the age of 21 days. Nos. 916 and 919 showed their first symptoms of purpura 7 days of age, but blood was demonstrated in urine and feces before that time. The purpura lasted to the 29th and 23rd day, respectively. No. 915 had purpura from the 17th to the 22nd day and no. 918 from the 17 th to the 26 th day. No. 917 had no distinct symptoms.

No leucopenia could be observed. To the contrary, the leucocyte number seemed to be slightly higher than normal. The PCV was low during the first week in all except nos. 915, 916 and 917. No. 919 had a moderate anemia, the lowest PCV being $24 \%$, while nos. 911, 912, 914 and 918 had a PCV as low as $13 \%, 16 \%$, $17 \%$ and $10 \%$ respectively.

Serum from the mother caused weak and atypical agglutinations when tested against the piglets' platelets.

b. S5 was mated again to another boar (L1) and farrowed a litter of 10 (nos. 1101-1110). Three of the piglets were killed by the mother the first day.

Platelet counts are shown in Fig. 10. Two of the piglets (nos. 1103 and 1108) had normal platelet counts all the time, no. 1104 


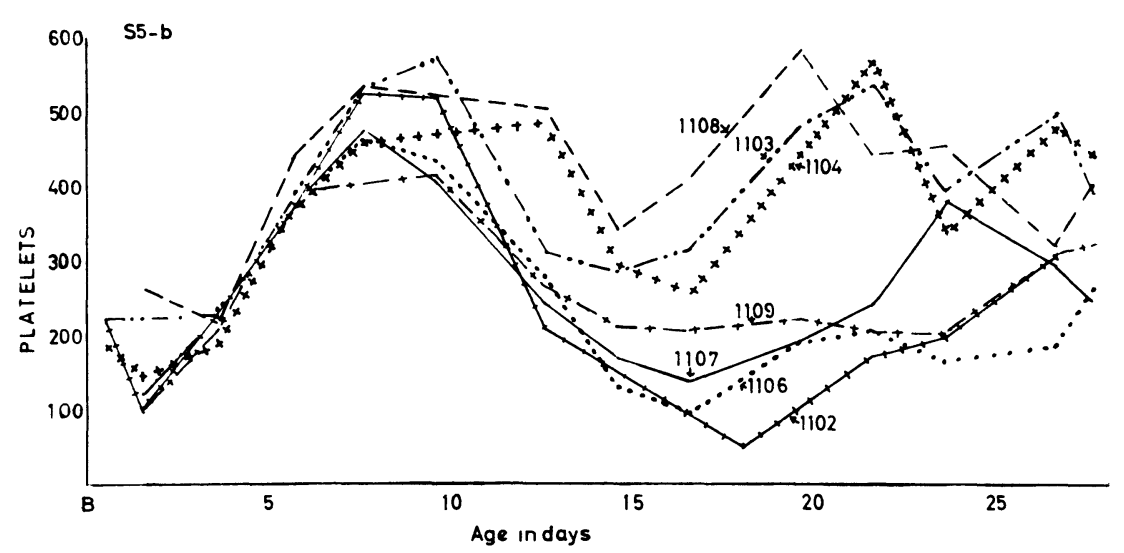

F ig u r e 10 . Platelet number in the offspring of S5 and boar L1.

had a slight thrombocytopenia the first 3 days, but normal platelet counts after that time. The remaining 4 piglets had a moderate thrombocytopenia the first 2 days and again at 2-3 weeks of age. Only 1, no. 1102, had weak symptoms of purpura that lasted for only 1 day, when 18 days old.

This time the serum from the mother agglutinated the platelets from her offspring. The positive reactions of the cells from nos. 1103 and 1104, however, were questionable as no agglutination could be seen by the first reading.

Within the litter a of S5, after mating to boar Y, the course of the disease differed from that seen in other cases as the piglets had a marked thrombocytopenia all through the first 3 weeks, without the increase in platelet number which usually is seen after the 3rd day of life. Within the next litter (b), however, after mating to boar L1, the disease had a milder course, but more similar to most other cases, as an increase in platelet number after the 3rd day was observed, followed by a second thrombocytopenia at about 2 weeks of age.

After this last pregnancy a platelet agglutinin could be demonstrated in the serum of the sow while the serum sample taken after the delivery of litter a, caused only weak and questionable reactions in an agglutination test.

S6. According to information, this sow had farrowed 5 litters reported to be normal, when she farrowed a litter of 10. Already at 1 day of age 4 piglets died showing severe symptoms of purpura. The next day, platelet counts were performed on the remaining 6 . All had counts from 15 to 65 . No further investigations were performed on 
this litter, but according to the owner, all the piglets survived and no purpura was seen after the 4th day of life.

a. S6 was mated to boar $Y$ and farrowed a litter of 16 of which 2 were killed by the mother during the first 2 days. Only 1 had weak symptoms of purpura the 1st day. Another one had slight purpura for only 1 day when 19 days old. The other 12 had no purpura, but all had moderate thrombocytopenia the first 2 days and some of them also at $2-3$ weeks of age. Moderate leucopenia was observed.

Platelets from all the piglets were agglutinated by the serum of the mother.

b. The sow was mated to boar L1 and farrowed a litter of 6 . All the piglets had platelet counts below 30 with purpura the first 2 days. Two died, 2 and 3 days old, possibly killed by the mother. The remaining 4 recovered and had normal platelet counts after the 4 th day of life.

All piglets from the litter a of S6 had a moderate thrombocytopenia which scarcely caused any symptoms of purpura. The next litter (b), however, had a pronounced purpura the first 2-3 days. In spite of that all piglets had normal platelet counts after the 4 th day of life.

\section{DISCUSSION}

In this country, thrombocytopenic purpura was observed for the first time in 1960 (Stormorken et al. 1963). As far as is known, the disease has not been reported in any other country before that time. During the last 7 years, however, 12 cases have been observed in this country, and at the same time, the disease has occurred in other Enropean countries. It is very difficult to explain why the disease has not been seen earlier and also the sudden appearance in different countries. Presumably, many cases of thrombocytopenia have not been observed because they have not resulted in purpura. Furthermore, even if piglets have purpura during the first 2 days of life, the symptoms at this time are not always so striking that they are registered. These facts, however, do not explain the apparently increasing number of fatal cases. It is possible that the condition is more or less characteristic of a certain breed, the Swedish Landrace. The Norwegian Landrace is namely highly influenced by this breed, 
due to importation of breeding animals. This breed has also been spread to many other countries.

One might also think of increased variation of platelet factors due to, for instance, increased mutation rates. Changes in environment with increased chances for the production of platelet antibodies would be another possibility. In this respect, one might think of antigenic factors in food or environment which crossreact with platelet factors, thereby being able to initiate or stimulate the platelet antibody production.

The usual course of the disease is remarkable due to the fact that the platelet number decreases during the first 2 days after birth, increases during the next few days, with a second decrease from about 1 week of age. This course is probably due to an effect of the platelet antibody, not only on the circulating platelets, but also on the bone marrow, because the bone marrow is severely affected in the fatal cases (Nordstoga 1965). The piglets investigated by Nordstoga died at an age of 8-20 days. In these piglets, a complete lack of normal megakaryocytes in the bone marrow was a constant finding, while the marrow of piglets of the same age, not exposed to platelet antibodies, had numerous megakaryocytes.

Piglets examined at $1 / 2-2$ days of age, however, usually have an apparently normal bone marrow. Of 10 such piglets with purpura (examined by the Department of Pathology, Veterinary College of Norway), only 1 had a reduced number of megakaryocytes.

The increase of platelets after the first decrease may be due to a yield from the megakaryocytes still left, or maybe, to a release of the platelets agglutinated by the antibodies during the first hours after birth. But, as the further production of platelets seems to be inhibited due to an effect on the bone marrow, there will be no new platelets, or only a reduced number, to replace the old ones. As the length of the platelets' life is 8-11 days (Leeksma \& Cohen 1956, Adelson et al. 1957), the platelet counts, therefore, will decrease gradually after a few days. Within the material investigated in the present report the platelet counts culminated at 5-8 days of age. The inhibition degree of the bone marrow function will probably be influenced by dose and titer of the antibody resorbed, the course thus depending on the intake of colostrum. 


\section{ACKNOWLEDGMENT}

I am very grateful to Professor Johs. L. Flatla for his encouragement and helpful advice, and for the facilities provided by him; and to Dr. Mikael Brænd for helpful criticism and advice.

I also wish to thank Mr. Lars Bjørsrud for his kind assistance by collecting the blood samples.

\section{REFERENCES}

Adelson, E., J. J. Rheingold \& W. H. Crosby: Studies of platelet survival by tagging in vivo with P32. J. Lab. clin. Med. 1957, 50, 570-576.

Dausset, J.: Normal and pathological platelet agglutinins investigated by means of the shaking method. Vox Sang. (Basel) 1954, 4, 204-213.

Henricson, B.: Personal communication 1964.

Henriksson, K.: Personal communication 1965.

Leeksma, C. H. W. \& J. A. Cohen: Determination of the life span of human blood platelets using labelled diisopropylfluorophosphonate. J. clin. Invest. 1956, 35, 964-969.

Lie, H.: The complexity of platelet antigens in pig. In Polymorphismes biochimiques des animaux. Xth European Conference on Animal Blood Groups and Biochemical Polymorphism 1966, 181-184.

Lie, $H$. .: Thrombocytes, leucocytes and packed red cell volume in piglets during the first two weeks of life. Acta vet. scand. 1968, 9, $105-111$.

Lundevall, J.: Serological studies of human blood platelets. Scand. J. clin. Lab. Invest. 1958, 10, Suppl. 34.

Nordstoga, K.: Thrombocytopenic purpura in baby pigs caused by maternal isoimmunization. Path. vet. 1965, 2, 601-610.

Saunders, C. N., D. A. Kinch \& P. Imlah: Thrombocytopenic purpura in pigs. Vet. Rec. 1966, 79, 549-550.

Stormorken, H., R. Svenkerud, P. Slagsvold, H. Lie \& J. Lundevall: Thrombocytopenic bleedings in young piglets due to maternal isoimmunization. Nature (Lond.) 1963, 198, 1116-1117.

Thörne, H. \& J. Håkanson: Thrombocytopeni hos smågrisar. Svensk Vet.-Tidn. 1967, 19, 589-590.

\section{SUMMARY}

A report is given about spontaneous as well as experimental cases of thrombocytopenia in baby pigs. A total of 14 litters from 6 sows were studied.

The piglets were normal at birth, but got thrombocytopenia after sucking. After $2-3$ days with low platelet counts which was sometimes accompanied by purpura the platelet number usually increased during the next few days and might reach a normal level at about 1 week of age. During the following week there was usually a second 
decrease which might result in purpura and death within a few days, but also might pass without clinical symptoms. Cases were observed where the piglets had thrombocytopenia, even with purpura the first day of life, but then had normal platelet counts all along after the first week.

In 1 experimental case, the piglets had a severe thrombocytopenia and purpura that lasted all during the first 3 weeks.

Differences were seen between litters of the same sow when this was sired by different boars.

In some cases of thrombocytopenia, a leucopenia was observed.

\section{ZUSAMMENFASSUNG}

Thrombozytopenische Purpura bei Saugferkeln.

Es wird ein Bericht über sowohl spontane wie experimentelle Fälle von Thrombozytopenie bei Saugferkeln gegeben. Insgesamt 14 Würfe von 6 Muttersäuen sind untersucht worden.

Die Ferkel waren bei der Geburt normal, bekamen jedoch Thrombozytopenie nachdem sie bei der Mutter gesaugt hatten. Nach 2-3 Tagen mit niedriger Thrombozytzahl, die zuweilen Purpurasymptome hervorrufen konnte, stieg die Thrombozytzahl im allgemeinen in den folgenden Tagen an und konnte etwa eine Woche nach der Geburt fast normale Werte erreichen. In der darauf folgenden Woche sank die Thrombozytzahl gewöhnlich wieder herab und konnte im Laufe von wenigen Tagen Purpura und den Tod der Tiere verursachen, konnte jedoch auch ohne klinische Symptome passieren.

Es wurden auch Fälle observiert in welchen die Ferkel in den ersten Lebetagen Thrombozytopenie und zuweilen Purpura zeigten, aber normale Thrombozytwerte nach dem Verlaufe einer Woche hatten.

In einem experimentellen Fall zeigten die Ferkel ausgesprochene Thrombozytopenie teilweise auch mit Purpura in den ganzen ersten 3 Lebewochen.

Es wurden Unterschiede im Krankheitsverlauf zwischen den Würfen von derselben Muttersau festgestellt, wenn diese von verschiedenen Ebern bedeckt worden war.

Bei einzelnen Thrombozytopeniefällen wurde auch Leukopenie festgestellt.

\section{SAMMENDRAG}

Trombocytopenisk purpura hos smågris.

Det er gitt en rapport over såvel spontane som eksperimentelle kasus av trombocytopeni hos smågris. I alt 14 kull fra 6 purker er unders $\phi$ kt.

Grisene var normale ved f $\varnothing$ dselen, men fikk trombocytopeni etter suging. Etter 2-3 dager med lavt trombocyttall, som enkelte ganger kunne resultere i purpurasymptomer, steg vanligvis trombocyttallet igjen de neste dagene og kunne nå nesten normale verdier ca. en uke etter fødselen. Den følgende uken sank vanligvis trombocyttallet igjen 
og kunne resultere i purpura og død innen få dager, men kunne også passere uten kliniske symptomer.

Det ble også observert tilfeller der grisene hadde trombocytopeni, og til og med purpura, den første levedagen, men hadde normale trombocytverdier etter den første uken.

I ett tilfelle hadde grisene uttalt trombocytopeni, delvis også med purpura, sammenhengende de første 3 leveuker.

Det ble observert forskjell i sykdomsforl $\varnothing$ pet mellom kullene fra samme purke når denne var bedekket med forskjellige råner.

I enkelte tilfeller med trombocytopeni ble det også observert leukopeni.

(Received April 22, 1968). 